\title{
Safe technological trend towards the production of bioethanol from algal biomass grown on rice straw
}

\author{
Ahmed Darwish El-Gamal ${ }^{1}$, Fawzy Gamal Khedr ${ }^{2}$, Eman Yousef \\ Tohamy ${ }^{2}$ and Ahmed Mohamed Abouelwafa ${ }^{3 *}$ \\ ${ }^{1}$ Botany and Microbiology Department, Faculty of science, Al-Azhar \\ University, Cairo, Egypt. \\ ${ }^{2}$ Botany and Microbiology Department, Faculty of science, Zagazig \\ University, Zagazig, Egypt. \\ ${ }^{3}$ Egyptian Ministry of Environment, Environmental Affairs Agency, Cairo, \\ Egypt.
}

\begin{abstract}
:
As a result of rapid growth in the population and manufacturing, the demand for ethanol is increasing continuously in worldwide. Because, biofuels produced from first and second-generation became unable to meet the international demand of bioethanol because of their needed value for food and feed. So, algae are among the most important sources of potential biofuels in the future of renewable energy because of accumulating high cellulose and also algae are distributed widely in the natural environment. This paper shows the ability of algae for bioethanol production, by pretreatment, hydrolysis, and fermentation of algal biomass. Two types of algae, Chlorella vulgaris and Arthrospira platensis were cultured under pre-treated rice straw with advantages as crop residues, a low-cost and carbon-rich source for algal cultivation. The chemical hydrolysates of rice straw (RS) were used for heterotrophic cultivation of Chlorella vulgaris and Arthrospira platensis for bioethanol production. Algal biomasses of the two microalgae were treated chemically with $4 \% \mathrm{H}_{2} \mathrm{SO}_{4}$ at $121^{\circ} \mathrm{C}$ in autoclave for $90 \mathrm{~min}$, followed by biological treatment with Bacillus subtilis for 72 hours at $30^{\circ} \mathrm{C}$ and $\mathrm{pH} 4.5$ to increase the reducing sugars production. The fermentation by Saccharomyces cerevisiae for 72 hours and distillation of Chlorella vulgaris and Arthrospira platensis solutions were resulted in ethanol productivity of $8.7 \%$ and $2.5 \%$ respectively after 24 hours at $30^{\circ} \mathrm{C}$ and $\mathrm{pH} 4.5$.
\end{abstract}

Keywords: Rice straw, Bioethanol, Chlorella vulgaris, Arthrospira platensis, Saccharification, Fermentation.

\section{Introduction}

Microalgae are a large group of microscopic photosynthetic organisms, there are several commercial advantages of algae bioethanol production. These 
advantages include. (i) For algal bioethanol there is no need to compete with food production in either land or water. Additionally, they also need not compete with people for food (Singh et al., 2011a) (ii) The content of carbohydrate in the algae cell is abundant; the carbohydrates such as starches and sugars can be fermented to produce bioethanol. (iii)Algae are specialized that they have no lignin and very low levels of hemicellulose, which result in an increased hydrolysis efficiency and fermentation yields (Choi et al., 2012; Eshaq et al., 2011); thus, they can reduce the cost of the bioethanol production. (iv) Algae have the ability to take up $\mathrm{CO} 2$ from the atmosphere and power plants, and with the use of appropriate technology options, algae bioethanols can yield (greenhouse gas) GHG reductions relative to fossil and other biobased fuels (Vasudevan et al., 2012; Singh et al., 2011b). (v) Algae grow rapidly and can be easily grown in various aquatic environments such as fresh water, saline water, or municipal waste water (Gouveia and Oliveira, 2009). (vi) They have a high photosynthetic efficiency; the average photosynthetic efficiency of aquatic biomass is 6-8\%, which is much higher than that of terrestrial biomass (1.8-2.2\%) (Ross $\boldsymbol{e t}$ al., 2008). Also, the microalgal cells have a very fast productivity and harvesting cycle (1-10 days) compared with other feedstock (harvest once or twice a year) and thus provide high biomasses level for bioethanol production (Schenk et al., 2008).

At the present time, algae conversion into bioethanol is recaptured attention as future biofuel feedstock in order to replace energy crops and cover any constraint in provide. Many species, especially marine algae are very suitable raw material for the production of different types of biofuels such as biodiesel, bioethanol, biogasoline, etc. and other chemicals (U.S. Department of Energy Biomass Program,2009). Also, Rodolfi et al. (2009) reports that algal biomass can provide about 60 times more alcohol than soybeans per acre of land. According to the study of Ferrel and Sarisky-Reed (2010) microalgae can provide amount of ethanol equal ten-fold more than corn per growing area. Harel (2009) state that microalgae have the ability to consuming high amounts of CO2 during their growth which make them very engaging to use as a friendly environmental feedstock. 
Like lignocellulosic ethanol, production of bioethanol from microalgae requires also four major unit operations including pretreatment, hydrolysis, fermentation, and distillation. Schematic flowsheet for the bioconversion of algal biomass to bioethanol is shown in Figure 1 (Kexun et al., 2014). In order to produce sugars from the algae biomass, pretreatment is designed to help separate cellulose, hemicellulose, and lignin so that the complex carbohydrate molecules in microalgae cells can be broken down by enzyme-catalyzed into simple sugars which are easy to be fermented into ethanol. Then the fermentable sugars can be fermented into ethanol by ethanol-producing microorganisms and finally recover and purify the ethanol to meet fuel specifications. Additionally, some separated solids can be recovered and utilized as a fuel to provide process heat and electricity at an alcohol production facility.

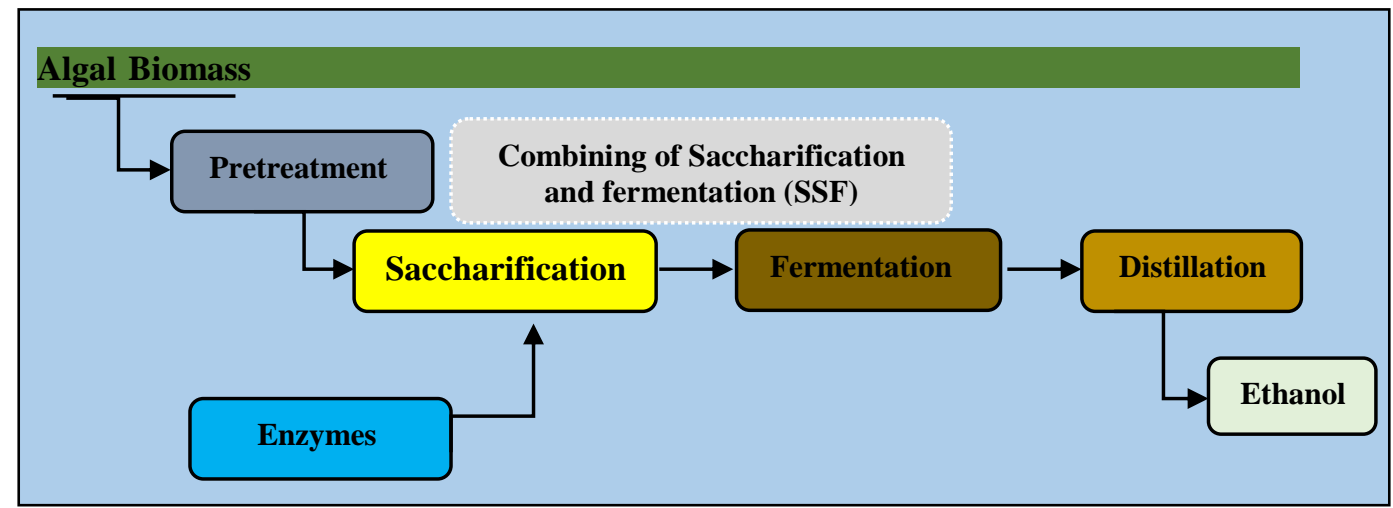

Figure 1. Steps of algae bioethanol production (Kexun et al., 2014).

Microalgal biomass feedstock is the most attractive, alternative renewable feedstock recently studied for bioethanol production (Al-Lwayzy et al., 2014; Lam and Lee, 2012). In general microalgae consist about $40 \%-70 \%$ of carbohydrate, about $10 \%$ - $20 \%$ of protein and little residues of low molecular weight compounds such as amines, fatty acid and amino acids. Take into consideration microalga feedstock is an enormous source for bioethanol production because of its high content of biomass carbohydrate (Brennan and Owende, 2010), fast growth rate, high photosynthetic efficiency, ability to fix 
greenhouse gases, non-competitive nature with food production, easily cultivated on non-agriculture site and have no lignin in their cell wall (Eshaq et al., 2011; Zhu et al., 2014).

Chlorella vulgaris has $37 \%$ - $55 \%$ of dry weight carbohydrate content which comes from starch found in the chloroplast and cellulose/hemicellulose found in the cell wall (Al-Lwayzy et al., 2014). Chlorella vulgaris can be cultivated in different ways heterotrophically, autotrophically or mixotrophically. Mixotrophic cultivation of Chlorella vulgaris in presence of organic carbon source produce higher levels of carbohydrate biomass than if it cultivated autotrophically (Miao et al., 2004; Ceron Garcia et al., 2000). When C. vulgaris cultivated in limited nitrogen and phosphorus medium, they utilize the carbon substrate easily result in production high quantities of lipid and carbohydrate simultaneously (Rigano et al., 1998). Residual crude glycerol obtained after biodiesel production, agricultural waste converted sugars and cellulosic materials, trapped $\mathrm{CO} 2$ which emitted from different industries and molasses production from sugar cane are cheap carbon substrates provide a good way to successful biomass production from microalgae. As a result of processing of plantain, the plantain peels are produced as byproducts. Plantain peels has high mineral contents of phosphorus and potassium, and thus it considered as a major source of carotenoids, polyphenols, dietary fiber and other bioactive compounds (Wolfe $\boldsymbol{e t}$ al., 2005). Under Mixotrophic condition, the utilization of Chlorella species feedstock using domestic fowl, such as chickens waste as a growth medium resulted in yielding of high biomass production $2.5 \mathrm{~g} / \mathrm{l}$ (Agwa et al., 2012). Most researchers attributed the ability of algal biomass for biodiesel production rather than bioethanol due to the low yield of sugars after hydrolysis of intracellular starch granules. Due to high cost of carbohydrate hydrolysis by enzyme mixture many researches have been developing simple technologies for such bioconversions such as combination of two chemical reagents; dilute acid or alkaline hydrolysis with enzyme in saccharification process (Hernandez et al., 2015).

Microalgae also are photosynthetic organisms have different polysaccharides. Some of these polysaccharides can be hydrolyzed through 
chemical and/or enzymatic processes to yield monosaccharides, which can then be fermented to produce bioethanol (Darzins et al., 2010). Examples for species that have a high carbohydrate content and are strong candidates for bioethanol production are Chlorococcum, Chlorella, Chlamydomonas, Scenedesmus, and Tetraselmis. Ethanol production varies depending on the types of hydrolysis strategies and fermentation processes used. Where recently, researchers became able to produce higher levels of sugars through treatment of different types of microalgae: $84-166.1 \mathrm{mg} / \mathrm{g}$ for Clostridium saccharoperbutylacetonicum (Castro et al., 2015); 58\% (w/w) Chlamydomonas reinhardtii of dry cell weight (Nguyen et al., 2009); release of 57-89.9\% of total sugars from Chlorella (Zhou et al., 2012; Lu et al., 2012), and $41.6 \%$ gulcose from Scenedesmus obliquus (Miranda et al., 2012a); and glucose yields greater than 90\% from Dunaliella tertiolecta (Geun et al.,2013), 46.92\% gulcose from C. vulgaris (Ho et al., 2013b). Ethanol can be excreted directly by microalgae through their cell walls, as shown for several organisms, including Chlorococcum humicola and Chlorococcum infusionum (Harun and Danquah,2011), Chlamydomonas reinhardtii (Choi et al., 2010), Chlorella vulgaris (Ho et al., 2013a), Scenedesmus obliquus (Ho et al., 2013b), Tetraselmis subcordiformis (Yao et al., 2013) and spirulina (Shimpei et al., 2013). Due to rigidity of cell wall of microalgae that may be more or less rigid structure therefore, it may be more difficult to break, such as in the case of Chlorella sp. that has a harder wall contrary to those of Scenedesmus sp. and cyanobacteria Arthrospira platensis. Therefore the pretreatments are required.

Carbon sources are usually the most critical and necessary factors for microalgal growth. In general, microalgae can be grown under photoautotrophic, heterotrophic, and Mixotrophic conditions using varied carbon sources, such as carbon dioxide $\left(\mathrm{CO}_{2}\right)$, methanol $\left(\mathrm{CH}_{3} \mathrm{OH}\right)$, acetate $\left(\mathrm{C}_{2} \mathrm{H}_{3} \mathrm{O}_{2}\right)$, glucose $\left(\mathrm{C}_{6} \mathrm{H}_{12} \mathrm{O}_{6}\right)$, or other organic compounds ( $\mathrm{Xu}$ et al, 2006). For photoautotrophic cultivation, the microalgae utilize inorganic carbon such as carbon dioxide $\left(\mathrm{CO}_{2}\right)$ or bicarbonates $(\mathrm{HCO}-3)$ as a carbon source to obtain the chemical energy through photosynthesis process (Ren et al., 2014). For heterotrophic cultivation, there are some species of microalgae have the ability to use the organic carbon as a carbon source directly and this is happening in the presence or absence of a light supply (Chojnacka and Noworyta, 2004). Although, the most commonly used carbon 
source for growth of microalgae and production of biofuels is still $\mathrm{CO}_{2}$ or $\mathrm{HCO}-3$, because using organic carbon sources would be very expensive for producing low-price products such as biofuels, this paper indicates another cheap carbon source for biofuel production, which is pretreated rice straw.

However, when the biofuels are directly converted from using $\mathrm{CO}_{2}$ as a substrate, $\mathrm{CO}_{2}$ emissions are reduced from a net-zero $\mathrm{CO}_{2}$ emission, thus reduces greenhouse effects in the environment. Particularly, photoautotrophic growth of microalgae Contributes to reutilization of $\mathrm{CO}_{2}$ gases which are coming often from flue gas of most power plants and nearly all industrial activities (Packer $\boldsymbol{e t}$ al., 2009), as microalgal biomass can be further utilized to produce biofuels or other value-added products (Hsueh et al., 2007).

In addition, when compared to terrestrial plants, most microalgae have much higher cell growth and $\mathrm{CO}_{2}$ fixation (about 10-50 times higher), and this gives proof of another advantage of direct conversion of photoautotrophic growth of microalgae into biofuels. Therefore, it is very important to trend to produce biofuels via photoautotrophic growth of microalgae, as this is important in terms of economy (i.e., cheap) and protection of the environment. However, microalgae grown under heterotrophic conditions have the ability to use organic carbon sources (e.g., sugars) to increase algal biomass content which in turn converted into biofuels. In this way, it is important to focus on biofuel production by heterotrophic cultivation of algae, since heterotrophic growth of microalgae is usually faster than autotrophic growth (Chen F. et al., 1996). So because of the high cost of obtaining the organic carbon sources from raw biomass is still a great concern, this paper focused on the production of biofuels from a cheap and available source of carbon; rice straw.

Chlorella vulgaris and Arthrospira platensis used for this study was cultivated in rice straw medium which is an excellent carbon source and a lowcost matter. The biomass extracted was exploited as a carbon source for bioethanol production by ordinary Simultaneous saccharification and fermentation process (SSF). 


\section{Materials and Methods}

\section{Rice straw treatment}

\subsection{Physical Pretreatment of rice straw}

Rice straw was sundried for 3 days, then chopped into $2 \mathrm{~cm}$ size by using chopper machine and was milled by milling machine to $1-2 \mathrm{~mm}$. As a result of good grinding of rice straw, the homogenized small size particles were obtained and used for further treatments.

\subsection{Chemical Pretreatment}

There are many chemical pretreatments were used, and the most promising chemical treatment for rice straw include oxidative and Acid-Hydrogen peroxide pretreatments. In chemical treatment; $10 \mathrm{~g}$ of rice straw was dissolved in $100 \mathrm{ml}$ of the chemical solution $\left(\mathrm{H}_{2} \mathrm{SO}_{4}\right.$ and/or $\left.\mathrm{H}_{2} \mathrm{O}_{2}\right)$ at ratio of 1:10 (w/v).

\subsection{Dilute Acid Pretreatment}

Acidic treatment is done at three different concentrations of Sulphuric acid were 2\% and 4\% (Anwar et al., 2012; Nikzad et al., 2012).

\subsection{Oxidative Pretreatment}

Hydrogen peroxide treatment was done at two different concentrations of Hydrogen peroxide were $4 \%$ and $6 \%$.

\subsection{Acid-Hydrogen Peroxide (AHP) Pretreatment}

Acid hydrogen peroxide treatment was done at two different concentrations of Sulphuric acid and Hydrogen peroxide were $2 \%$ and $4 \%$ respectively.

All the above flasks were the autoclaved at $121^{\circ} \mathrm{C}$, at 15 psi. for 60 and 90 minutes with control flasks. After treatment, the samples were filtered after a 
while with cheese cloth. The samples were then washed out gently, first with the tap water and then with the distilled water (Nikzad $\boldsymbol{e t}$ al., 2012). The samples were air dried and then dried at oven at $105^{\circ} \mathrm{C}$ for one hour, then stored in the refrigerator at $4^{\circ} \mathrm{C}$ for further use. The filtrate solution was preserved for Dinitrosalicylic acid (DNS) analysis to determine the concentration of reducing sugars present in that samples.

\subsection{Microorganisms}

The cyanobacterium Arthrospira platensis and green algae $C$. vulgaris used in the present study was obtained from the laboratory of Microbiology, faculty of science, University of AL-Azhar, Cairo, Egypt. Arthrospira platensis was maintained in $500 \mathrm{~mL}$ sterilized Erlenmeyer flasks containing $100 \mathrm{~mL}$ Zarrouk's medium at $25 \pm 2^{\circ} \mathrm{C}, \mathrm{pH} 10.5$ (Zarrouk et al.,1966), while C. vulgaris was maintained in $500 \mathrm{~mL}$ sterilized Erlenmeyer flasks containing $100 \mathrm{~mL}$ BlueGreen 11 medium (BG11) at $25 \pm 2{ }^{\circ} \mathrm{C}, \mathrm{pH} 9$ (Marrez et al., 2013), with continuous illumination using white fluorescent tubes (2500 Lux) and daily shaking by hand three times.

\section{Cultivation of algae on pretreated rice straw}

Firstly, 90ml of Zarrouk's medium was poured in two "250 ml conical flasks" and $\mathrm{pH}$ was adjusted to 10.5 , flasks were autoclaved at $121^{\circ} \mathrm{C}$ for $30 \mathrm{~min}$, then adding one gram of chemically pretreated rice straw to the first flask and one gram of untreated rice straw to the second flask, then each flask was inoculated with $10 \mathrm{ml}$ freshly prepared Arthrospira platensis. Secondly, 90ml of Blue-Green 11 medium was poured in two "250 ml conical flasks" and $\mathrm{pH}$ was adjusted to 9 , flasks were autoclaved at $121^{\circ} \mathrm{C}$ for $30 \mathrm{~min}$, then adding one gram of chemically pretreated rice straw to the first flask and one gram of untreated rice straw to the second flask, then each flask was inoculated with $10 \mathrm{ml}$ freshly prepared $C$. vulgaris.

All flasks were kept at room temperature at $\left(25 \pm 1^{\circ} \mathrm{C}\right)$ under natural day and dark period (approximately, 12:12) for 15 days (Agwa et al.,2012). Cultures of algae were shaken three times every day. After 15 days, microalgal suspension 
was centrifuged, and pellets were washed thoroughly with distilled water and dried at $60^{\circ} \mathrm{C}$ until constant weight.

\section{Filtration of Algal biomass}

The growth conditions were observed after two day intervals for the algal cell growth and biomass calculations. Samples were filtered, collected, and subsequently analyzed for optical density (abs) determination using UV spectrophotometer (Lee et al., 2014). The cell dry weight was measured using a centrifuge at 12,000 rpm for 15 mins. The residue was washed twice with physiological saline $(0.85 \% \mathrm{w} / \mathrm{v}, \mathrm{NaCl})$, dried in an oven at $60^{\circ} \mathrm{C}$ in a pre-weighed filter paper until constant weight. The amount of dried microalgae was measured as cell dry weight (El-Sheekh et al., 2014). The biomass productivity was calculated according to Ho et al., (2012).

\section{Pretreatment of algal biomass}

Algal biomass was treated chemicaly with $4 \% \mathrm{H}_{2} \mathrm{SO}_{4}$ then bilogicaly with Bacillus subtilis. Biomass pretreatment is one of the most crucial and expensive process steps in the process of converting biomass to fermentable sugars (Harun et al., 2011), and pretreatment is estimated to reduce about $33 \%$ of the total cost (Choi et al., 2010).

\subsection{Acid hydrolysis pretreatment}

Algal biomass was subjected to dilute acid pretreatment using $4 \%$ (2N $\mathrm{H}_{2} \mathrm{SO}_{4}$ ), autoclaved at $121^{\circ} \mathrm{C}$ for 120 mins and neutralized to $\mathrm{pH} 4.5$ using citrate buffer.

\subsection{Biological treatment of algal biomass}

Biological treatment using various types of rot fungi or bacteria, a safe and environmentally friendly method, that does not require high energy for lignin removal from a lignocellulosic biomass (Kumar et al., 2009). Bacillus subtilis has been used for bio-hydrolysis of algal biomass after chemical pretreatment. 


\section{Bacterial Inoculum Preparation}

Medium was inoculated with $100 \mu \mathrm{l}$ of Bacillus subtilis and incubated at $30^{\circ} \mathrm{C}$ for $72 \mathrm{~h}$ then used for inoculation of fermentation yeast.

\section{Yeast Inoculum Preparation}

S. cerevisiae was inoculated in $100 \mathrm{ml}$ YPD medium (Ausubel $\boldsymbol{e}$ t al., 1994) under sterilized conditions and was incubated at $30^{\circ} \mathrm{C}$ for $24 \mathrm{~h}$. After incubation the culture was centrifuged for $5 \mathrm{~min}$ at $4000 \mathrm{rpm}$ and pellets were washed with sterilized distilled water then were suspended in sterilized distilled water for inoculation immediately.

\subsection{Simultaneous Saccharification and Fermentation (SSF)}

The strains Bacillus subtilis and Saccharomyces cerevisiae were grown in Basal Media were added in $500 \mathrm{ml}$ of distilled water and make up the volume to $1000 \mathrm{ml}$ ( Mandels et al., 1962; Mukhopadhyay and Nandi , 1998; Karimi et al., 2006) and $\mathrm{pH}$ of the media was adjusted to 4.5 using citrate buffer at $25^{\circ} \mathrm{C}$. The media was then autoclaved at $121{ }^{\circ} \mathrm{C}$ and 15 psi for 30 minutes. $5 \%$ dextrose was added after the autoclaving of media (Sharma et al., 2007). $100 \mathrm{ml}$ of this media was then poured in each of $250 \mathrm{ml}$ of flask containing 400 milligrams of pretreated algal biomass. $100 \mu 1$ of Bacillus subtilis was then inoculated in each of these flasks under sterile conditions and then incubated at $30^{\circ} \mathrm{C} \pm 2^{\circ} \mathrm{C}$ on the rotary shaker at $120 \mathrm{rpm}$ for $72 \mathrm{~h}$. The sampling from these flasks was done for Dinitrosalycilic Acid (DNSA) analysis for estimation of sugar contents, where the solution was centrifuged at $9000 \mathrm{rpm}$ for 15 mins and stored as sugar hydrolysate for the fermentation (Miranda et al., 2012b; Dhull et al., 2014). After 72 hours $S$. cerevisiae was inoculated in the same flasks for the process of fermentation, at an initial yeast cell concentration of approximately $1 \times 10^{7}$ cells $/ \mathrm{mL}$ and incubated on the rotary shaker at $150 \mathrm{rpm}$ at $30^{\circ} \mathrm{C}$ for another $72 \mathrm{~h}$. Sampling was done every 24 hours for DNSA analysis at $540 \mathrm{~nm}$.

\subsection{Filtration and Distillation Process}

Samples were then filtered by using cheese cloth to separate the solid substrate from liquid and then distillation was done at $78.37^{\circ} \mathrm{C}$ to get the ethanol samples for $\mathrm{GC}$ analysis.

Egyptian J. of Phycol. Vol. 20, 2019 


\subsection{Analytical methods}

\subsubsection{Estimation of reducing sugars}

For reducing sugar estimation: 3,5-dinitosalicyclic acid method was used. By adding $1 \mathrm{ml}$ of DNS reagent to $1 \mathrm{ml}$ of each of the sample then boiled for 5 mins and diluted with $10 \mathrm{ml}$ of distilled water. The absorbance was determined at $540 \mathrm{~nm}$ using UV-VIS spectrophotometer. The concentration value was extrapolated from the glucose standard curve (Itelima et al., 2013).

\subsubsection{Estimation of ethanol concentration}

Dubios chromate method was used for ethanol estimation (Dubois et al., 1956). $5 \mathrm{ml}$ of each sample was treated with $2 \mathrm{ml}$ of chromate reagent. The mixture was allowed to stand for an hour and the absorbance measured at $588 \mathrm{~nm}$ using UV-VIS spectrophotometer (Rabah et al., 2011).

\subsubsection{Distillation process}

Method according to Oyeleke and Jibrin (2009); was used for distillation of the fermentation medium to ethanol. the temperature of heating $78^{\circ} \mathrm{C}$ was used to heat the bottom of flask until completely distilled. The ethanol percentage resulted from distillation was estimated from ethanol standard curve.

\section{Results}

\section{Chemical composition of Rice Straw (RS) before and after treatment}

Chemical composition of rice straw before and after chemical treatment was shown in table (1). Where cellulose, hemicellulose and lignin for Untreated RS is $38.26 \%, 25.92 \%$ and $11.28 \%$ respectively and after Acid-Hydrogen peroxide treatment of RS it became $46.65 \%, 18.86 \%$ and $8.32 \%$ respectively, while it was so slightly in untreated specimens where, $38.98 \%, 25.21 \%$ and $10.01 \%$ for cellulose, hemicellulose and lignin respectively. 
Table 1: Chemical composition of Rice straw before and after chemical treatment

\begin{tabular}{|c|c|c|c|}
\hline Composition & Cellulose (\%) & Hemicellulose (\%) & Lignin (\%) \\
\hline Untreated RS (Native straw) & 38.26 & 25.92 & 11.28 \\
\hline \multicolumn{4}{|c|}{ After Chemical treatment } \\
\hline Acid-Hydrogen peroxide treatment of RS & 46.65 & 18.86 & 8.32 \\
\hline Sulfuric acid treatment of RS & 39.15 & 12.36 & 10.38 \\
\hline Hydrogen peroxide treatment of RS & 40.55 & 14.47 & 9.05 \\
\hline
\end{tabular}

\section{Chemical treatment of RS}

Acid hydrogen peroxide pretreatment at $121^{\circ} \mathrm{C}$ for 90 mins. was the effective pretreatment in hydrolysis of rice straw than acid or peroxide treatments, where the strength of acid and hydroxyl radicals $(\bullet \mathrm{OH})$ are extremely powerful oxidizing agents that can catalyze highly non-specific reactions leading to the cleavage of covalent bonds in both lignin and cellulose (Hammel et al.,2002) (Table 2).

Figure (2) shows that reducing sugars from rice straw increased after 90 mins. of treatments at $121^{\circ} \mathrm{C}$ than pretreatments of another chemical either after 60 mins nor 90 mins. So rice straw pretreated with Acid hydrogen peroxide after 90 mins. was used for cultivation of algae.

Table 2: Reducing sugars from rice straw after different chemical treatments

\begin{tabular}{|c|c|c|c|c|c|c|c|}
\hline \multicolumn{8}{|c|}{ Reducing sugars mg/ml } \\
\hline & 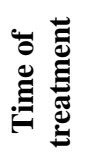 & 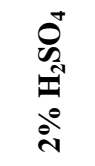 & $\begin{array}{l}0^{+} \\
\underbrace{-1} \\
0 \\
0 \\
0\end{array}$ & 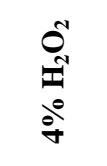 & 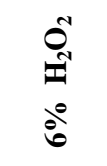 & 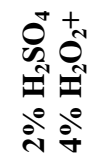 & 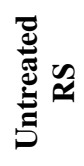 \\
\hline \multirow{2}{*}{$\begin{array}{l}\text { Autoclave } \\
\text { At } 121 \mathrm{C}^{\circ}\end{array}$} & $60 \mathrm{~min}$ & 99.23 & 118.48 & 104.56 & 147.39 & 166.93 & 9.91 \\
\hline & $90 \mathrm{~min}$ & 117.60 & 175.85 & 126.56 & 190.33 & 250.56 & 9.93 \\
\hline
\end{tabular}




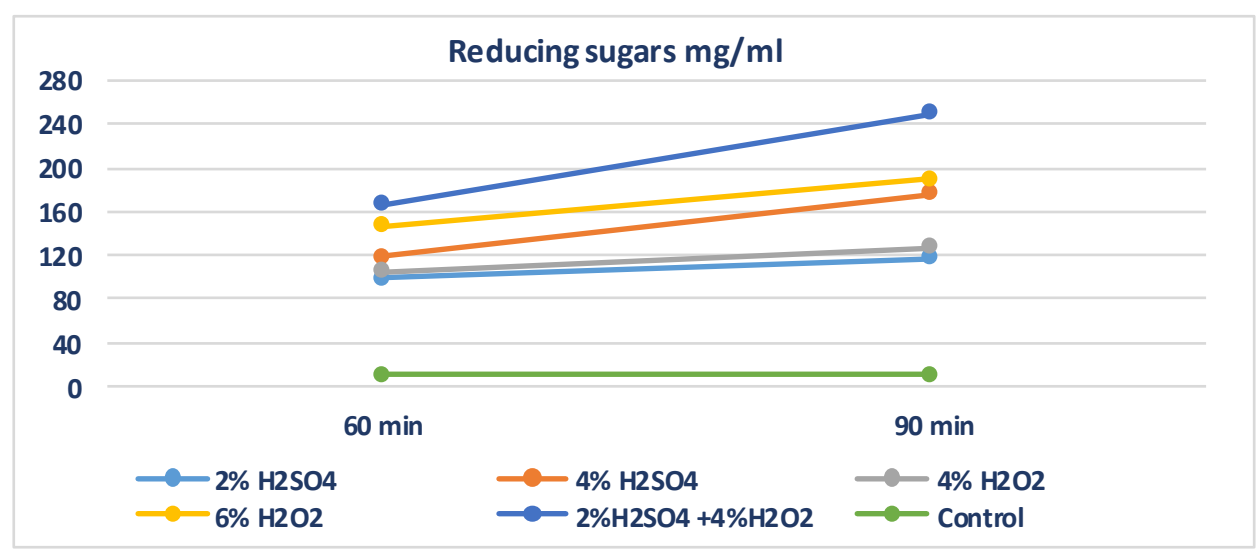

Figure 2. Reducing sugars results from rice straw after different chemical treatments

\section{Cultivation of Microalgae on RS as a carbon source}

Microalgae Chlorella vulgaris and Arthrospira platensis were grown under heterotrophic conditions using chemically treated rice straw as a carbon sources (sugars) for bioethanol production.

\subsection{Growth rate of Microalgae}

The cell growth of microalgae was determined by measuring the Optical Density (OD) at $680 \mathrm{~nm}$ using a spectrophotometer. It has been found that growth rate of Chlorella vulgaris on chemically pretreated rice straw medium is better than Arthrospira platensis (Figure 3).

The microalgae Chlorella vulgaris, particularly, has been considered as a promising feedstock for bioethanol production because it can accumulate up to $37 \%$ (dry weight) of starch. However, higher starch contents can also be obtained for optimized culture conditions (Nguyen, 2012). 


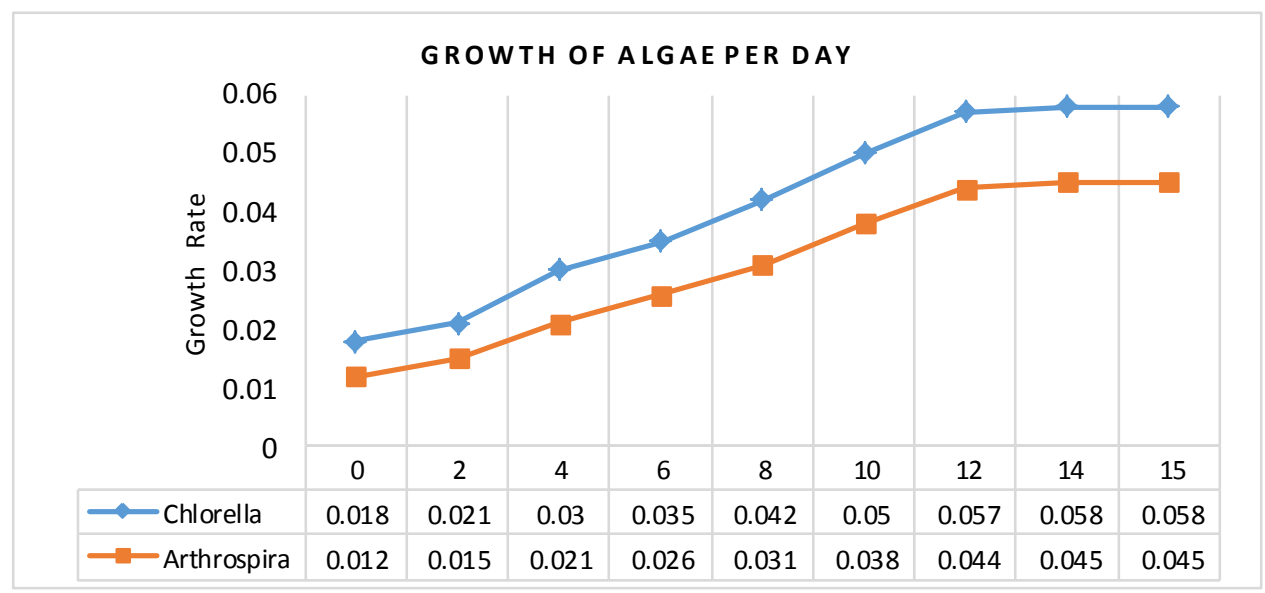

Figure (3). Growth curve of Chlorella vulgaris and Arthrospira platensis in pretreated rice straw

\subsection{Algal biomass}

The addition of carbon source (RS) had significant effects on the biomass productivity in C. vulgaris and Arthrospira platensis. Biomass productivity of Chlorella vulgaris was $0.56 \mathrm{~g} / \mathrm{L}$ was significantly higher $(\mathrm{p}<0.05)$ biomass productivity of Arthrospira platensis $0.45 \mathrm{~g} / \mathrm{L}$ (Table 3).

Table (3): Biomass productivity of Chlorella vulgaris and Arthrospira platensis

\begin{tabular}{|c|c|}
\hline Microalgae & Biomass productivity (g /L) \\
\hline C. vulgaris & $\mathbf{0 . 5 6} \pm \mathbf{0 . 0 6}$ \\
\hline Arthrospira platensis & $\mathbf{0 . 4 5} \pm \mathbf{0 . 0 2}$ \\
\hline
\end{tabular}

\subsection{Reducing sugars after cultivation of algal growth}

Table (4) shows the quantities of reducing sugars consumed by Chlorella vulgaris or Arthrospira platensis during the cultivation of each of them on chemically pretreated rice straw. Reducing sugars were measured every $48 \mathrm{~h}$. 
Table (4): Reducing sugars consumed by Chlorella vulgaris and Arthrospira platensis

\begin{tabular}{|c|c|c|c|c|}
\hline \multicolumn{5}{|c|}{$\begin{array}{l}\text { Reducing sugars }(\mathrm{mg} / \mathrm{ml}) \\
\text { Algal cultivation on pretreated RS for } 15 \text { days at } 25^{\circ} \mathrm{c}\end{array}$} \\
\hline & \multicolumn{2}{|c|}{ Chlorella vulgaris } & \multicolumn{2}{|c|}{ Arthrospira platensis } \\
\hline Time/day & $\begin{array}{c}\text { RS-Treated with } \\
2 \% \mathrm{H}_{2} \mathrm{SO}_{4}+4 \% \mathrm{H}_{2} \mathrm{O}_{2}\end{array}$ & Control & $\begin{array}{c}\text { RS-Treated with } \\
2 \% \mathrm{H}_{2} \mathrm{SO}_{4}+4 \% \mathrm{H}_{2} \mathrm{O}_{2}\end{array}$ & Control \\
\hline $\mathbf{0}$ & 242.53 & 11.52 & 242.78 & 11.52 \\
\hline 2 & 239.03 & 11.01 & 240.78 & 11.35 \\
\hline 4 & 233.48 & 10.34 & 239.04 & 11.10 \\
\hline 6 & 226.61 & 9.40 & 236.18 & 11.09 \\
\hline 8 & 221.93 & 9.23 & 234.97 & 11.05 \\
\hline 10 & 219.76 & 9.14 & 233.38 & 10.90 \\
\hline 12 & 218.89 & 8.70 & 233.27 & 10.60 \\
\hline 14 & 218.00 & 8.60 & 232.45 & 10.51 \\
\hline
\end{tabular}

It was found that Chlorella vulgaris has been consumed $24.53 \mathrm{mg} / \mathrm{ml}$ of reducing sugars from the medium as a carbon source after 15 days of its cultivation, while Arthrospira platensis has been consumed a significant amount of reducing sugars $10.33 \mathrm{mg} / \mathrm{ml}$ after 15 days of its cultivation (Figure 4).

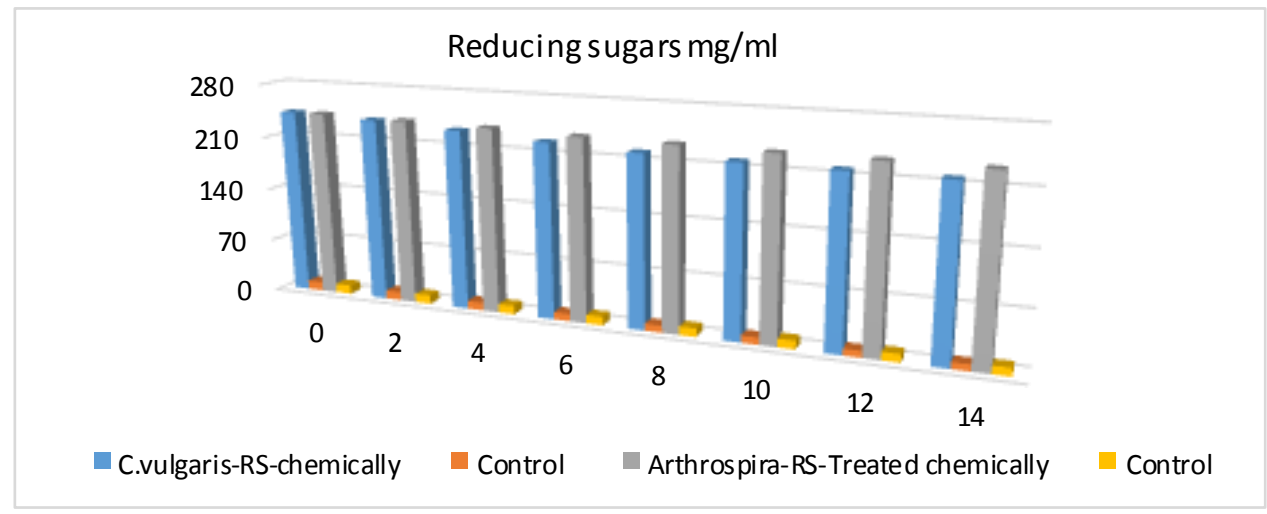

Figure (4). Reducing sugars concentration after cultivation of Microalgae. 


\subsection{Chemical treatment of Algal biomass}

Table (5) shows that carbohydrate extracted biomass had initial sugar composition of 32.68 and $14.78 \mathrm{in} \mathrm{mg} / \mathrm{ml}$ after acid hydrolysis process for Chlorella vulgaris and Arthrospira platensis with $4 \% \mathrm{H}_{2} \mathrm{SO}_{4}$ at $121^{\circ} \mathrm{C}$ in autoclave for 90 min respectively.

Table (5): Reducing sugars from algal biomass treated with $4 \% \mathrm{H}_{2} \mathrm{SO}_{4}$ at $121{ }^{\circ} \mathrm{c}$ in autoclave for $90 \mathrm{~min}$

\begin{tabular}{|c|c|c|c|c|}
\hline \multicolumn{5}{|c|}{$\begin{array}{l}\text { Reducing sugars }(\mathrm{mg} / \mathrm{ml}) \\
\text { Algal biomass treated With } 4 \% \mathrm{H}_{2} \mathrm{SO}_{4} \text { at } 121{ }^{\circ} \mathrm{c} \text { in autoclave for } 90 \mathrm{~min}\end{array}$} \\
\hline & Chlorella vulgaris & control & Arthrospira platensis & control \\
\hline $\begin{array}{c}\text { Reducing } \\
\text { sugars mg/ml }\end{array}$ & 32.68 & 3.15 & 14.78 & 1.72 \\
\hline
\end{tabular}

Acid hydrolysis treatment is more effective with Chlorella vulgaris compared to Arthrospira platensis, where it gives more reducing sugars (Figure 5).

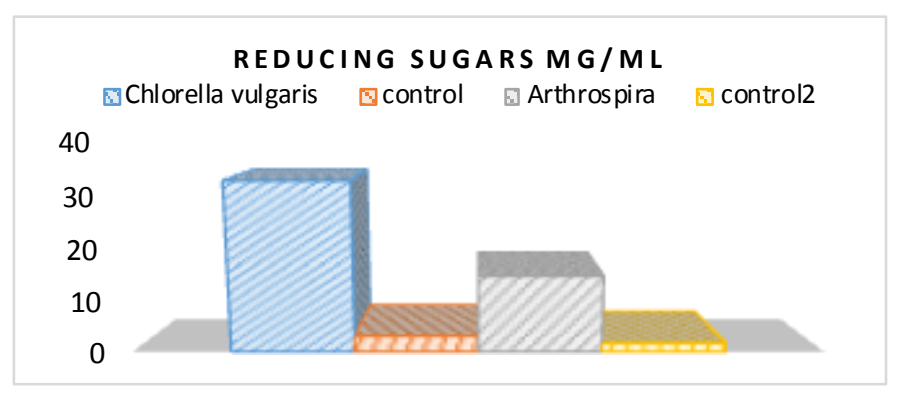

Figure (5). Reducing sugar concentration after acid hydrolysis of algae.

\subsection{Biological treatment of Algal biomass}

The hydrolysis of algae with Bacillus subtilis resulted in carbohydrate extracted biomass had initial sugar composition of $33.54,35.85$ and $36.78 \mathrm{mg} / \mathrm{ml}$ 
for Chlorella vulgaris after $24 \mathrm{~h}, 48 \mathrm{~h}$ and $72 \mathrm{~h}$ and respectively while for Arthrospira platensis the sugars were $14.90,16.89$ and $17.64 \mathrm{mg} / \mathrm{ml}$ after $24 \mathrm{~h}$, $48 \mathrm{~h}$ and $72 \mathrm{~h}$ and respectively (Table 6).

Table (6): Reducing sugars from algal biomass treated with Bacillus subtilis for 72h at $30{ }^{\circ} \mathrm{C}$ and $\mathrm{PH} 4.5$

\begin{tabular}{|c|c|c|c|c|}
\hline \multicolumn{5}{|c|}{ Reducing sugars (mg/ml) } \\
\hline Algal biomass treated with Bacillus subtilis for $72 \mathrm{~h}$ at $30{ }^{\circ} \mathrm{C}$ PH 4.5 \\
\hline Time of hydrolysis & Chlorella vulgaris & control & Arthrospira & control \\
\hline $24 \mathrm{~h}$ & 33.54 & 3.20 & 14.90 & 1.77 \\
\hline $48 \mathrm{~h}$ & 35.85 & 3.64 & 16.89 & 1.90 \\
\hline $72 \mathrm{~h}$ & 36.78 & 4.11 & 17.64 & 1.96 \\
\hline
\end{tabular}

Biological treatment is favored for algal biomass after chemical treatment for more reducing sugars production to reach maximum results of ethanol percent after fermentation of sugars by yeast. It has been found that biological treatment results in high reducing sugars for Chlorella vulgaris compared to Arthrospira platensis (Figure 6).

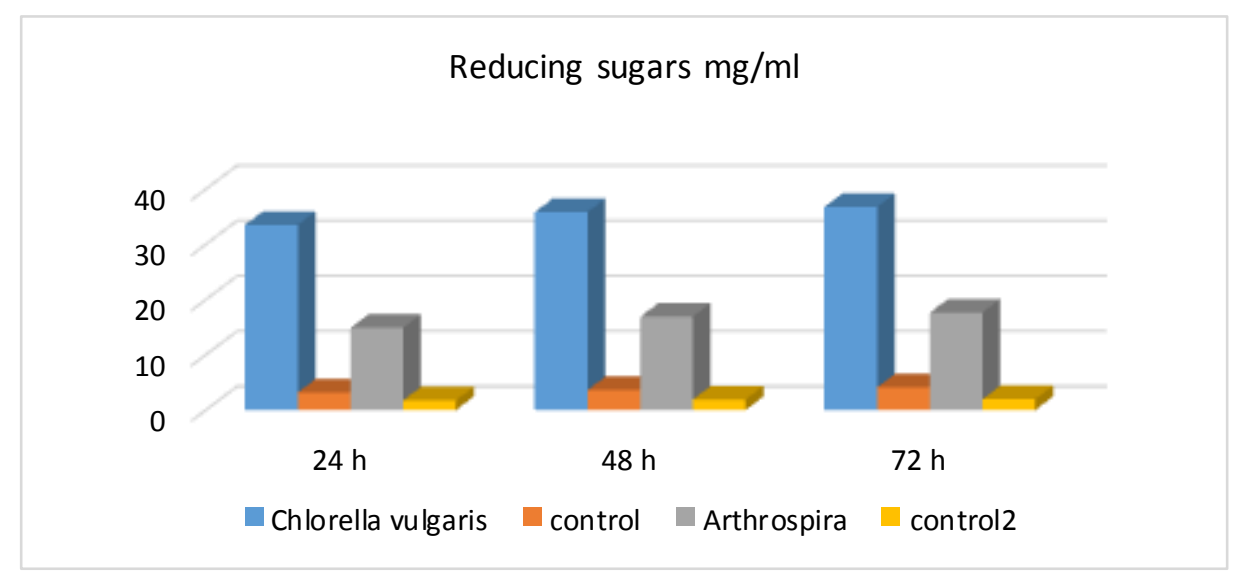

Figure (6). Reducing sugar concentration after biological hydrolysis of algae. 


\subsection{Fermentation of Algal biomass}

After three days fermentation at $30^{\circ} \mathrm{C}$ and $\mathrm{pH} 4.5$, the reducing sugar was consumed highly by fermentation broth inoculated with Bacillus subtilis, followed by inoculation of $S$. cerevisiae. Most of reducing sugars produced from algal feedstock were fermented by $S$. cerevisiae into ethanol determined by GC.

\subsection{Ethanol Determination}

\subsubsection{Ethanol Yield (Ethanol productivity)}

The highest ethanol produced from fermentation of algal biomass was after $24 \mathrm{~h}$ of fermentation then it was gradually decreased (table 7). Ethanol productivity was $8.7 \%$ from Chlorella vulgaris after 24h, while for Arthrospira platensis it was only $2.5 \%$ ethanol productivity after $24 \mathrm{~h}$ of fermentation by Saccharomyces cerevisiae for at $30^{\circ} \mathrm{C}$ and $\mathrm{pH} 4.5$.

Table (7): Ethanol productivity \% from pretreated Algal biomass at different incubation times

\begin{tabular}{|c|c|c|c|c|}
\hline \multicolumn{5}{|c|}{$\begin{array}{c}\text { Ethanol productivity (\%) } \\
\text { (ml of ethanol per } 100 \mathrm{~mL} \text { of media) }\end{array}$} \\
Algal biomass fermented With Saccharomyces cerevisia for $72 \mathrm{~h}$ at $30{ }^{\circ} \mathrm{C}$ & $\mathrm{pH} 4.5$ \\
\hline Time of fermentation & $\begin{array}{c}\text { Chlorella } \\
\text { vulgaris }\end{array}$ & Control & Arthrospira & control \\
\hline $24 \mathrm{~h}$ & 8.7 & - & 2.5 & - \\
\hline $48 \mathrm{~h}$ & 7.2 & - & 1.8 & - \\
\hline $72 \mathrm{~h}$ & 7.1 & - & 1.3 & - \\
\hline
\end{tabular}

Ethanol productivity results indicates that fermentation of Chlorella vulgaris produce ethanol more than Arthrospira platensis at the same conditions of fermentation (Figure 7). 


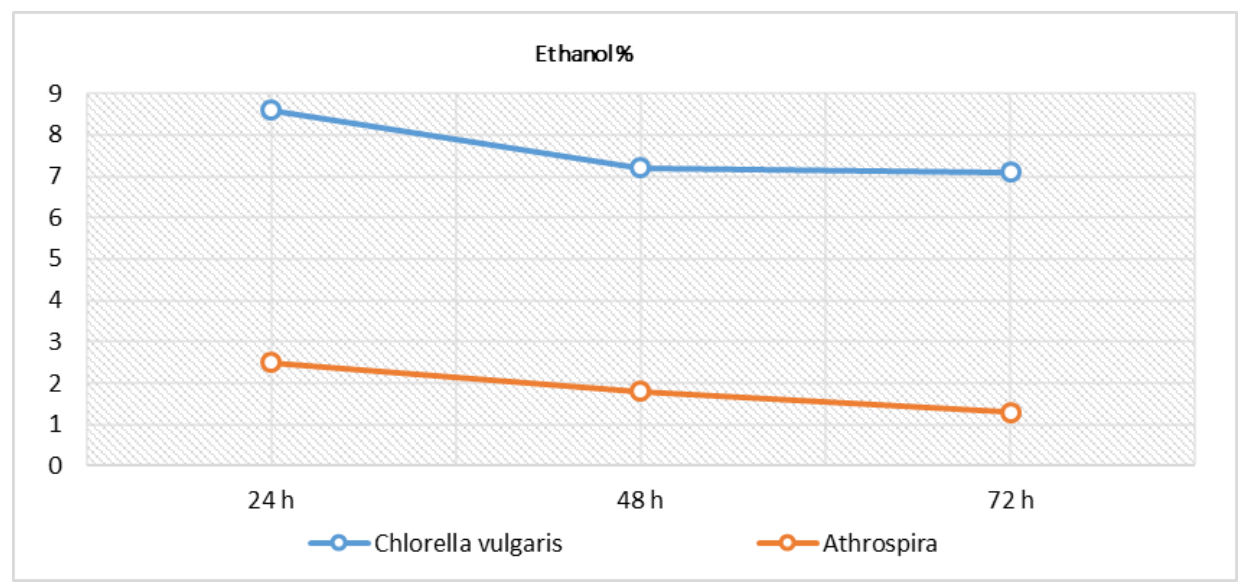

Figure (7). Ethanol productivity of pretreated rice straw during fermentation with Saccharomyces cerevisiae

\subsubsection{GC Analysis}

The results of fermentation were obtained using a GC. There was a gradual decrease in the amount of ethanol produced with fermentation time from one day to third days. The results of fermentation are shown in figure $(\mathbf{8 a}, \mathbf{b}$ and $\mathbf{c})$ where the ethanol percent produced after fermentation of pretreated algal biomass with Saccharomyces cerevisiae was $8.7 \%$ and $2.5 \%$ for Chlorella vulgaris and Arthrospira platensis respectively after 24 hours at $30^{\circ} \mathrm{C}$ and $\mathrm{pH} 4.5$, then the ethanol percent is gradually decreased at the third day of fermentation. 


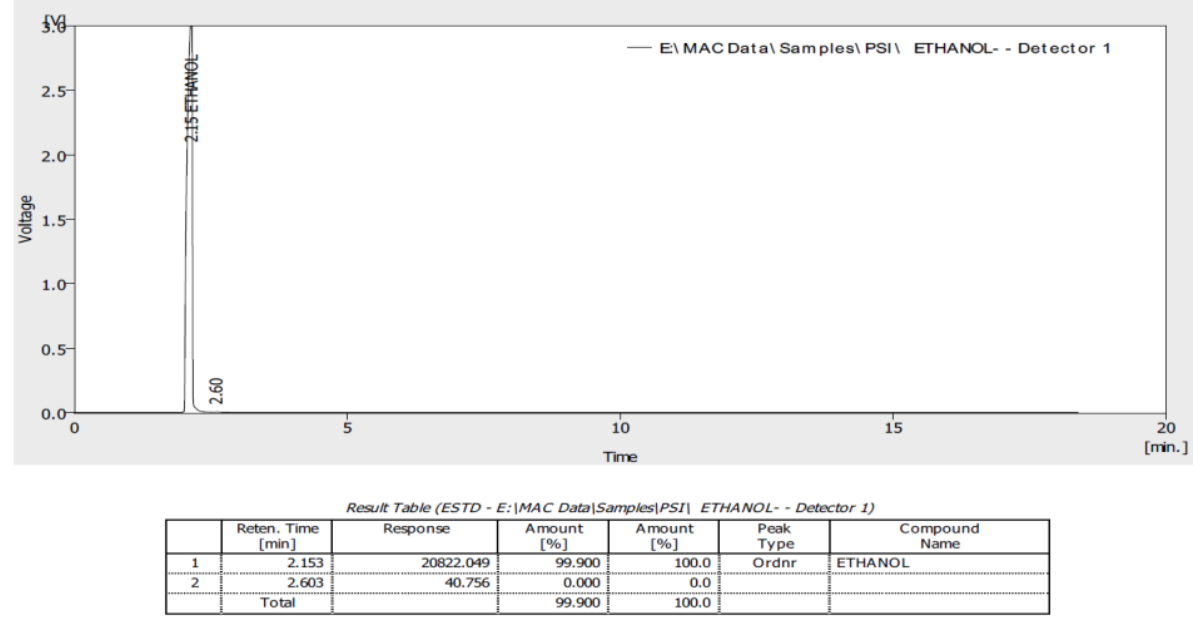

(a)

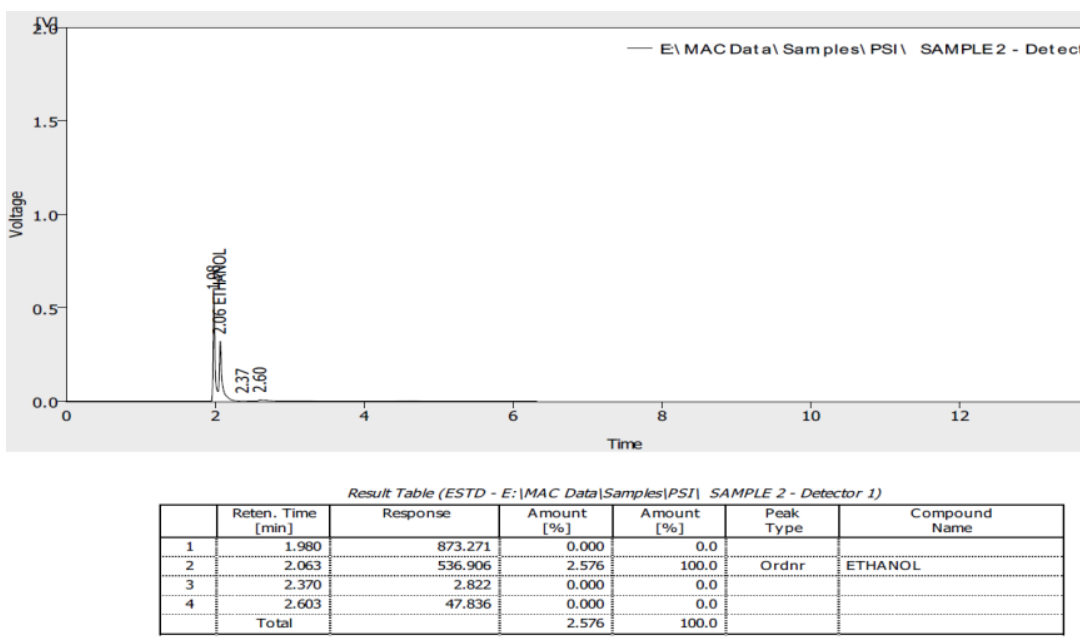

(b)

Egyptian J. of Phycol. Vol. 20, 2019

-70 - 


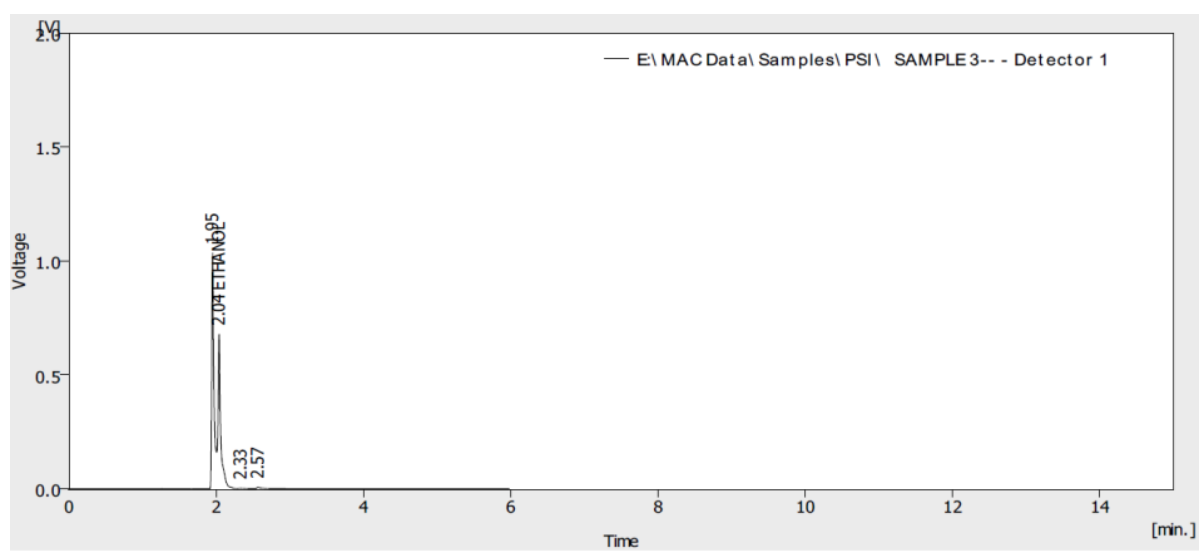

\begin{tabular}{|c|c|c|c|c|c|c|}
\hline & $\begin{array}{c}\text { Reten. Time } \\
{[\mathrm{min}]}\end{array}$ & Response & $\begin{array}{c}\text { Amount } \\
{[\%]}\end{array}$ & $\begin{array}{c}\text { Amount } \\
{[\%]}\end{array}$ & $\begin{array}{l}\text { Peak } \\
\text { Type }\end{array}$ & $\begin{array}{c}\begin{array}{c}\text { Compound } \\
\text { Name }\end{array} \\
\end{array}$ \\
\hline 1 & 1.950 & 2209.849 & 0.000 & 0.0 & & \\
\hline 2 & 2.040 & 1818.087 & 8.723 & 100.0 & Ordnr & ETHANOL \\
\hline 3 & 2.333 & 15.017 & 0.000 & 0.0 & & \\
\hline \multirow[t]{2}{*}{4} & 2.567 & 31.749 & 0.000 & 0.0 & & \\
\hline & Total & & 8.723 & 100.0 & & \\
\hline
\end{tabular}

(c)

Figure (8). GC Analysis of Ethanol \% (a) Pure ethanol, Ethanol from (b) Arthrospira platensis and Ethanol from (c) Chlorella vulgaris

\section{Discussion}

In this study, low cost rice straw which also is available in Egypt in large quantities, was treated as a rich source of carbohydrate for cultivation of two types of microalgae, namely green algae (Chlorella vulgaris) and blue green algae (Arthrospira platensis), for the production of bioethanol after being chemically treated with diluted sulfuric acid and then biologically using bacterium Bacillus subtlilis for breaking down polysaccharides into simple sugars are easily fermented by Saccharomyces cerevisiae yeast to produce bioethanol. Rice straw treated with Acid hydrogen peroxide at $121^{\circ} \mathrm{C}$ for $90 \mathrm{~min}$ resulted in high production of reducing sugars than sulfuric acid (4\%) or hydrogen peroxide $(6 \%)$ pretreatments at the same conditions, where it was $250.56,175,85$ and 190.33 
$\mathrm{mg} / \mathrm{ml}$ for Acid hydrogen peroxide (AHP), sulfuric acid and hydrogen peroxide pretreatments respectively (Figure 2), also lignin was reduced to $8.32 \%$ by AHP pretreatment as compared to untreated RS $(11.28 \%)$, sulfuric acid pretreatment $(10.38 \%)$ or hydrogen peroxide pretreatment $(9.05 \%)$ and This is evident in Table (1) results. This is compatible to the study by Long et al. (2005), Jahan et al. (2006) and Karin Walter (2009). Pretreated rice straw with AHP considered a new chemical treatment added to other chemical treatments of rice straw for bioethanol production. So, it used for cultivation of microalgae Chlorella vulgaris and Arthrospira platensis.

Results of cultivation of microalgae Chlorella vulgaris and Arthrospira platensis for 15 days, heterotrophically on rice straw pretreated with AHP as a carbon source showed in Figure (3). it has been found that, maximum biomass of Chlorella vulgaris $(0.56 \mathrm{~g} / \mathrm{l})$ is somewhat higher than of Arthrospira platensis $(0.45 \mathrm{~g} / \mathrm{l})$ at the same conditions (Table 3). This is analogous to Krystian et al. (2014) and is consistent with the results of Sibi (2015). Reducing sugars from pretreated rice straw have been reduced slightly in the mediums of both Chlorella vulgaris and Arthrospira platensis during the cultivation period, indicating that these microalgae can be cultivated on low cost carbon source lignocellulosic substances such as rice straw (Figure 4), and this is analogous to Penglin $\boldsymbol{e t}$ al. (2011) and Rouf et al. (2019).

The results of microalgal biomass treatment (Chlorella vulgaris and Arthrospira platensis) by dilute sulfuric acid showed in Figure 5, indicated the effectiveness of chemical treatment in the hydrolysis of microalgal biomass, where it resulted in increasing the amount of reducing sugars from algal biomass, this is agreement with Lee $\boldsymbol{e t}$ al. (2011) and Laurens $\boldsymbol{e t}$ al. (2015). Reducing sugars resulted from $C$. vulgaris biomass $(32.68 \mathrm{mg} / \mathrm{ml})$ better than those from Arthrospira platensis $(14.78 \mathrm{mg} / \mathrm{ml})$ due to the good exploitation of carbon source by $C$. vulgaris than Arthrospira platensis.

The results of this study demonstrated that cellulolytic enzymes of Bacillus subtilis can be used for microalgae biomass hydrolysis with greater advantages (Haipeng et al., 2017). The yield of the reducing sugars from its hydrolysis is lower than that from dilute acid hydrolysis indicating that saccharification activities of the enzyme are not adequate. 
The microalgal biomass hydrolysates in this work were fermented by Saccharomyces cerevisiae. Co-culture fermentation by Bacillus subtilis and $S$. cerevisiae yielded highest ethanol during the fermentation period after $24 \mathrm{~h}$. and then ethanol percent decreased. This may be due to various mixtures of sugars such as hexoses and pentoses released into the hydrolysates which cannot be utilized by S. cerevisiae (Van et al., 2006). Bacillus subtilis is capable of producing carbohydrate hydrolases and certain enzymes like amylases, cellobiases, xylanases which degrade the non-starch polysaccharides resulting to related increase in the amount of soluble sugars available in the fermentation broth (Huang and Tang, 2007; Panneerselvam and Elavarasi, 2015) . The susceptibility of some sugars obtained after hydrolysis by Bacillus subtilis during the fermentation process to the fermentable activity of $S$. cerevisiae became higher causing corresponding increase in ethanol yield. The result of this study agrees with the study production of ethanol by simultaneous saccharification of Bacillus subtilis and S. cerevisiae fermentation of potato wastes which stated that most substrates were utilized for ethanol production in co-culture fermentation (Elsayed et al., 2015).

High Bioethanol resulted from microalgal biomass fermentation was after $24 \mathrm{~h}$ at $\mathrm{pH} 4.5$ and $30^{\circ} \mathrm{C}$ where it was $8.7 \%$ from C. vulgaris and $2.5 \%$ from Arthrospira platensis, then bioethanol decreased (Figures 788). Although the amount of ethanol produced is few (8.7\%) compared with the amount of ethanol produced by Ragaa et al. (2017) which is $40 \%$, But it is a promising and encouraging to complete the study of bioethanol production from microalgal biomass after cultivation on the low-cost carbon source rice straw.

\section{Conclusion}

Utilization of crop waste materials for algal biomass is a promising approach to meet the increasing energy needs as a substitute for fossil fuels. This work provides an important strategy using rice straw as a potential carbon source in microalgal cultivation for bioethanol production and showed that pretreated rice straw can be utilized by $C$. vulgaris and Arthrospira platensis which provides a 
feasible route of reducing production cost of bioethanol from a cheap carbon substrate for biomass and bioenergy production.

Although the slightly quantities of ethanol produced by algae in this study, the results are good and promising for the future production of ethanol from algal biomass, beside another benefits such as,

- Increase the carbohydrate content of microalgae

- Isolation and selection of potential algal strains

- Optimization of their growth in various environments

- proper selection of yeast strain for improved fermentation

- proper knowledge and identification of biochemical triggers, and pretreatment methods and enzymatic methods, they help to improved fermentation process, so that automatically improvement in ethanol yield from algae.

\section{References}

Agwa, O.K., Ibe, S.N. and Abu, G.O. (2012). Economically Effective Potential of Chlorella sp. for Biomass and Lipid Production. Journal of Microbiology Biotechnology Resource, 2, 34-45.

Al-Lwayzy, H.S., Yusaf, T. and Al-Juboori, R.A. (2014). Biofuel from Fresh Water Microalgae Chlorella vulgaris [FWM-CV] for Diesel Engines. Energies, 7, 1829-1951.

Anwar, Z., Gulfraz, M., Asad, M.J., Imran, M., Akram, Z., Mehmood, S., Rehman, A., Anwar, P. and Sadiq, A. (2012). Bioethanol productions from rice polish by optimization of dilute acid pretreatment and enzymatic hydrolysis. African Journal of Biotechnology, 11,992-998.

Ausubel, F.M., Brent, R., Kingston, R.E., Moore, D.D., Seidman, J.G., Smith, J.A. and Struhl, K. (1994). Current Protocols in Molecular Biology. Current Protocols Brooklyn, New York. Dev 8, 1726- 1737. 
Brennan, L. and Owende, P. (2010). Biofuels from Microalgae-A Review of Technologies for Production, Processing and Extractions of Biofuels and Co-Products. Renewable Sustainable Energy Revision, 14, 557-577.

Castro, Y.A., Ellis, J.T., Miller, C.D., Sims, R.C. (2015). Optimization of wastewater microalgae saccharification using dilute acid hydrolysis for acetone, butanol, and ethanol fermentation. Applied Energy 140, 14-19.

Ceron Garcı, M.C., Fernandez Sevilla, J.M., Acien Fernandez, F.G., Molina Grima, G. and Garcia Camacho, F. 2000. Mixotrophic Growth of Phaeodactylum tricornutum on Glycerol: Growth Rate and Fatty Acid Profile. Journal of Applied Phycology, 12, 239-248.

Chen, F., Zhang, Y. and Guo, S. (1996). Growth and phycocyanin formation of Spirulina platensis in photoheterotrophic culture. Biotechnology Letters, 18(5), 603-608.

Choi, W.Y., Han, J.G., Lee, C.G., Song, C.H., Kim, J.S., Seo, Y.C., Lee, S.E., Jung, K.H., Kang, D.H., Heo, S.J., Cho, J.S. and Lee, H.Y. (2012). Bioethanol production from Ulva pertusa Kjellman by high-temperature liquefaction. Chemical and Biochemical Engineering Quarterly; 26(1):15-21.

Choi, S.P., Nguyen, M.T. and Sim, S.J. (2010). Enzymatic pretreatment of Chlamydomonas reinhardtii biomass for ethanol production. Bioresource Technology, 101(14):5330-5336.

Chojnacka, K. and Noworyta, A. (2004). Evaluation of Spirulina sp. growth in photoautotrophic, heterotrophic and mixotrophic cultures. Enzyme Microb. Technol. 34, 461-465.

Darzins, A., Pienkos, P. and Edye, L. (2010). Current status and potential for algal biofuels production - a report to IEA Bioenergy Task 39, Report T39-T2.

Dhull, N., Gupta, K. and Kumar, S. (2014). Heterotrophic and Mixotrophic Cultivation of Chlorella pyrenoidosa and the Enzymatic Hydrolysis of Its Biomass for the Synthesis of Third Generation Bioethanol. Peer Journal 2: e483v1.

Dubois, M., Giller, K.A., Hamilton, J.K., Roberts, P.A. and Smith, F. (1956). Colorimetric Method for Determination of Sugars and Related Substances. Analytical Chemistry, 28, 350-356. 
Elsayed B. Belal, Mona A. Farid and A. A. Abo-Shosha. (2015). Int.J.Curr.Microbiol.App.Sci, 4(7), 511-524.

El-Sheekh, M.M., Gharieb, M.M., El-Sabbagh, S.M. and Hamza, W.T. (2014). Antimicrobial Efficacy of Some Marine Macroalgae of Red Sea. International Journal of Microbiology and Immunology Research, 3, 2128.

Eshaq, F.S., Ali, M.N. and Mohd, M.K. (2011). Production of bioethanol from next generation feed-stock alga Spirogyra species. International Journal of Engineering, Science and Technology, 3(2), 1749-1755.

Ferrel, J and Sarisky-Reed, V. (2010). National algal biofuels technology roadmap. US Department of Energy. Office of Energy and Renewable Energy, (202)586-5340.

Sibi, G. (2015). Low Cost Carbon and Nitrogen Sources for Higher Microalgal Biomass and Lipid Production Using Agricultural Wastes. Journal of Environmental Science and Technology 8 (3): 113-121.

Geun Goo, B., Baek, G., Jin Choi, D., Il Park, Y., Synytsya, A., Bleha, R., Ho Seong, D., Lee, C-G. and Kweon Park, J. (2013). Characterization of a renewable extracellular polysaccharide from defatted microalgae Dunaliella tertiolecta. Bioresource Technology, 129, 343-350.

Gouveia, L. and Oliveira, A.C. (2009). Microalgae as a raw material for biofuels production. Journal of Industrial Microbiology and Biotechnology, 36(2):269-274.

Haipeng Guo, Houming Chen , Lu Fan, Andrew Linklater, Bingsong Zheng, Dean Jiang and Wensheng Qin. (2017). Enzymes produced by biomassdegrading bacteria can efficiently hydrolyze algal cell walls and facilitate lipid extraction. Journals \& Books, 109, 195-201.

Hammel, K. E., Kapich, A. N., Jensen Jr., K. A. and Ryan, Z. C. (2002). Reactive oxygen species as agents of wood decay by fungi, Enzyme Microb. Technol. 30(4), 445-453.

Harel, A. (2009). Noritech Seaweed Biotechnologies Ltd, Algae World Conference. Rotterdam, The Netherlands, 23: 44-53.

Harun, R. and Danquah, M.K. (2011). Influence of acid pre-treatment on microalgal biomass for bioethanol production. Process Biochemistry, 46, 304-309. 
Harun, R., Jason, W.S.Y., Cherrington, T. and Danquah, M.K. (2011). Exploring alkaline pre-treatment of microalgal biomass for bioethanol production. Applied Energy, 88(10):3464-3467.

Hernandez, D., Riano, B., Coca, M. and Garcia-Gonzalez, M.C. 2015. Saccharification of Carbohydrates in Microalgal Biomass by Physical, Chemical and Enzymatic Pretreatments as a Previous Step for Bioethanol Production. Chemical Engineering Journal, 262, 939-945.

Ho, S.H., Chen, C.Y. and Chang, J.S. (2012). Effect of light intensity and nitrogen starvation on $\mathrm{CO} 2$ fixation and lipid/carbohydrate production of an indigenous microalga Scenedesmus obliquus CNW-N. Bioresour. Technol., 113: 244-252.

Ho, S-H., Li, P-J., Liu, C-C. and Chang, J-S. (2013a). Bioprocess development on microalgae-based $\mathrm{CO} 2$ fixation and bioethanol production using Scenedesmus obliquus CNW-N. Bioresource Technology, 145, 142-149.

Ho, S-H., Huang, S-W., Chen, C-Y., Hasunuma, T., Kondo, A. and Chang, JS. (2013b). Bioethanol production using carbohydrate-rich microalgae biomass as feedstock. Bioresource Technology, 135, 191-198.

Hsueh, H.T., Chu, H. and Yu S.T. (2007). A batch study on the biofixation of carbon dioxide in the absorbed solution from a chemical wet scrubber by hot spring and marine algae. Chemosphere, 66, 878-886.

Itelima, J., Ogbonna, A., Pandukur, S., Egbere, J. and Salami, A. (2013). Simultaneous Saccharification and Fermentation of Corn-Cobs to Bioethanol by Co-Culture of Aspergillus niger and Saccharomyces cerevisiae. International Journal of Environmental Science development, 4, 329-342.

Karimi, K., Emtiazi, G. and Taherzadeh, M.J. (2006). Ethanol production from dilute-acid pretreated rice straw by simultaneous saccharification and fermentation with Mucor indicus, Rhizopus oryzae, and Saccharomyces cerevisiae. Enzyme and Microbial Technology, 40,138-144.

Karin Walter. (2009). INFLUENCE OF ACID HYDROGEN PEROXIDE TREATMENT ON REFINING ENERGY AND TMP PROPERTIES. Sundsvall, Sundsvall, Sweden, ISSN 1652-8948. 
Kexun, Li, Shun Liu and Xianhua Liu. (2014). An overview of algae bioethanol production, International Journal of Energy Research. DOI: 10.1002/er.3164.

Krystian Miazek, Claire Remacle, Aurore Richel and Dorothee Goffin. 2014. Effect of Lignocellulose Related Compounds on Microalgae Growth and Product Biosynthesis. Energies, 7, 4446-4481.

Kumar, P., Barrett, D.M., Delwiche, M.J. and Stroeve, P. (2009). Methods for pretreatment of lignocellulosic biomass for efficient hydrolysis and biofuel production. Industrial \& Engineering Chemistry Research; 48(8):3713-3729.

Laurens, L. M. L., Nagle, N., Davis, R., Sweeney, N., Van Wychen, S., Lowell A. and Pienkos., P. T. (2015). Acid-catalyzed algal biomass pretreatment for integrated lipid and carbohydrate-based biofuels production. Green Chem., 17, 1145.

Lam, M.K. and Lee, K.T. (2012). Microalgae Biofuels: A Critical Review of Issues, Problems and the Way Forward. Biotechnology Advances, 30, 673-690.

Lee, C.G., Choi, W.Y., Kang, D.H. and Lee, H.Y. (2014). Simultaneous Production of Biodiesel and Bioethanol through Mixotrophic Cultivation of Chlorella sp. Indian Journal of Geo -Marine Science, 43, 519528.

Lee, S., Oh, Y., Kim, D., Kwon, D., Lee, C., Lee, J. (2011). Converting carbohydrates extracted from marine algae into ethanol using various ethanolic Escherichia coli strains. Applied Biochemistry and Biotechnology; 164(6):878-888.

Long Khama, Yves Le Bigot, Michel Delmas and Gérard Avignon. (2005). Delignification of wheat straw using a mixture of carboxylic acids and peroxoacids. Industrial Crops and Products, 21: 9-15.

Lu, S., Wang, J., Niu, Y., Yang, J., Zhou, J. and Yuan, Y. (2012). Metabolic profiling reveals growth related FAME productivity and quality of Chlorella sorokiniana with different inoculum sizes. Biotechnology and Bioengineering, 109, 1651-1662.

Mandels, M., Parrish, F.W. and Reese, E.T. (1962). Sophorose as an inducer of cellulase in Trichoderma reesei. Journal of Bacteriology., 83,400-408. 
Marrez, D.A.; Naguib, M.M.; Sultan, Y.Y.; Daw, Z.Y.; Higazy, A.M. 2013. Impact of Culturing Media on Biomass Production and Pigments Content of Spirulina platensis. Int. J. Adv. Res., 1, 951-961.

Matthew, J. Scholz, Mark R. Riley and Joel, L. Cuello. (2013). Acid hydrolysis and fermentation of microalgal starches to ethanol by the yeast Saccharomyces cerevisiae. Biomass and Bioenergy, 48, 59-65.

Miao, X., Wu, Q. and Yang, C. (2004). Fast Pyrolysis of Microalgae to Produce Renewable Fuels. Journal of Analytical and Applied Pyrolysis, 71, 855863. https://doi.org/10.1016/j.jaap.2003.11.004

Miranda, J.R., Passarinho, P.C., Gouveia, L. (2012a). Bioethanol production from Scenedesmus obliquus sugars: the influence of photobioreactors and culture conditions on biomass production. Bioenergy and Biofuels, 96, $555-564$.

Miranda, J.R., Passarinho, P.C. and Gouveia, L. (2012b). Pretreatment Optimization of Scenedesmus obliquus Microalga for Bioethanol Production. Bioresource Technology, 104, 342-348. https://doi.org/10.1016/j.biortech.2011.10.059

Mukhopadhyay, S. and Nandi, B. (1998). Optimization of cellulase produce by T. reesei ATCC 26921 using a simplified medium on water hyacinth biomass. J Sci Ind Res., 58,107-111.

Nguyen, M.T., Choi, S.P., Lee, J., Lee, J.H. and Sim, S.J. (2009). Hydrothermal acid pretreatment of Chlamydomonas reinhardtii biomass for ethanol production. Journal of Microbiology and Biotechnology, 19, 161-166.

Nguyen, T.H.M. (2012). Bioethanol production from marine algae biomass: prospect and troubles, Journal of Vietnamese Environment, 3(1), 25-9.

Nikzad, M., Movagharnejad, K., Najafpour, G.D., Talebnia, F. (2012). Comparative Studies on the Effect of Pretreatment of Rice Husk on Enzymatic Digestibility and Bioethanol Production IJE TRANSACTIONS B: Applications., 26,455-464.

Oyeleke, S.B. and Jibrin, N.M. (2009). Production of Bioethanol from Guinea Cornhusk and Millet Husk. African Journal of Microbiology Research, 3, 147-152. 
Packer, M. (2009). Algal capture of carbon dioxide; biomass generation as a tool for greenhouse gas mitigation with reference to New Zealand energy strategy and policy.Energy Policy, 37, (9), 3428-3437.

Panneerselvam, T. and Elavarasi, S. (2015). Int.J.Curr.Microbiol.App.Sci, 4(2), 543-552.

Penglin Li, XiaolingMiao, Rongxiu Li and Jianjiang Zhong. (2011). In Situ Biodiesel Production fromFast-Growing and High Oil Content Chlorella pyrenoidosa in Rice Straw Hydrolysate. Journal of Biomedicine and Biotechnology, 10,141207- 141215.

Rabah, A.B., Oyeleke, S.B., Manga, S.B. and Hassan, L.G. (2011). Utilization of Millet and Guinea Corn Husk for Bioethanol Production. African Journal of Microbiology Research, 5, 5721-5724.

Ragaa A. Hamouda, Shaimaa, A. Sheri, Mohammed M. Ghareeb. (2017). Bioethanol Production by Various Hydrolysis and Fermentation Processes with Micro and Macro Green Algae. Waste Biomass Valor, 10,9936-9943

Raoof, B. (2006). Formulation of a low-cost medium for mass production of Spirulina. Biomass and Bioenergy, 30, (6), 537-542.

Ren, H. Y., Liu, B. F., Kong, F., Zhao, L., Xie, G. J. and Ren, N. Q. (2014). Enhanced lipid accumulation of green microalga Scenedesmus sp. by metal ions and EDTA addition. Bioresource Technology, 169, 763-767.

Rigano, V.D.M., Vona, V., Esporto, S., Carillo, P., Carfagna, S. and Rigano, C. (1998). The Physiological Significance of Light and Dark Ammonium Metabolism in Chlorella sorokiniana. Photochemistry, 47, 177-181.

Rodolfi, L., Zitelli, G.C., Bassi, N., Padovani, G., Biondi, N. and Bionini, G. (2009). Microalgae for oil: Strain selection, induction of lipid synthesis and outdoor mass cultivation in a low-cost photo-bioreactor. Biotechnol Bioeng, 102,100-12.

Rouf Ahmad Dara, Mehak Arorab and Urmila Gupta Phutela. (2019). Optimization of cultural factors of newly isolated microalga Spirulina subsalsa and its co-digestion with paddy straw for enhanced biogas production. Bioresource Technology Reports, 5,185-198.

Ross, A.B., Jones, J.M., Kubacki, M.L. and Bridgeman, T. (2008). Classification of macroalgae as fuel and its thermochemical behaviour. Bioresource Technology; 99(14), 6494-6504. doi: 10.1016/j.biortech.2007.11.036. 
Schenk, P.M., Thomas-Hall, S.R., Stephens, E., Marx, U.C., Mussgnug, J.H., Posten, C., Kruse, O. and Hankamer, B. (2008). Second generation biofuels: high-efficiency microalgae for biodiesel production. Bioenergy Research;1(1), 20-43. doi:10.1007/s12155-008-9008-8.

Sharma, N., Kalra, K.L., Oberoi, H.S. and Bansal, S. (2007). Optimization of fermentation parameters for production of ethanol from kinnow waste and banana peels by simultaneous saccharification and fermentation. Indian J. Microbiol., 47,310-316.

Shimpei Aikawa,ab Ancy Joseph, Ryosuke Yamada, Yoshihiro Izumi, Takahiro Yamagishi, Fumio Matsuda, Hiroshi Kawai, Jo-Shu Chang, Tomohisa Hasunumabch and Akihiko Kondo. (2013). Direct conversion of Spirulina to ethanol without pretreatment or enzymatic hydrolysis processes.Energy \& Environmental Science. 6, 1844-1849.

Singh, A., Nigam, P.S. and Murphy, J.D. (2011a). Renewable fuels from algae: an answer to debatable land-based fuels. Bioresource Technology; 102(1):10-16.

Singh, A., Olsen, S.I. and Nigam, P.S. (2011b). Aviable technology to generate third-generation biofuel. Journal of Chemical Technology and Biotechnology; 86(11):1349-1353. doi:10.1002/Jctb.2666.

Talebnia, F., Karakashev, D. and Angelidaki, I. (2010). Production of bioethanol from wheat straw: an overview on pretreatment, hydrolysis and fermentation. Bioresource Technology; 101(13):4744-4753. doi:10.1016/j. biortech.2009.11.080.

U.S. Department of Energy Biomass Program. (2009). http://www.eere.energy.gov/biomass/pdfs/biomass.deep.dive.pir.pdf.

Van Maris, A.J, Abbott, D.A, Bellissimi, E., van den Brink, J., Kuyper, M., Luttik, M.A., Wisselink, H.W., Scheffers, W.A., van Dijken, J.P. and Pronk, J.T. (2006). Alcoholic fermentation of carbon sources in biomass hydrolysates by Saccharomyces cerevisiae. Antonie Van Leeuwenhoek, 90, 391-418.

Vasudevan V, Stratton RW, Pearlson MN, Jersey GR, Beyene AG, Weissman JC, Rubino M and Hileman JI. (2012). Environmental performance of algal biofuel technology options. Environmental Science and Technology; 46(4):2451-2459. doi:10.1021/es2026399. 
Wei-ChoHuang and I-ChingTang. (2007). Chapter 8 - Bacterial and Yeast Cultures - Process Characteristics, Products, and Applications. New Technologies and Applications, 185-223.

Wolfe, D.W., Schwartz, M.D., Lakso, A.N., Otsuki, Y., Pool, R.M. and Shaulis, N.G. (2005). Climate Change and Shifts in Spring Phenology of Three Horticultural Woody Perennials in Northeastern USA. International Journal of Biometerology. 49, 303-309. https://doi.org/10.1007/s00484004-0248-9

Xu, H., Miao, X. and Wu, Q. (2006). High Quality Biodiesel Production from a Microalga Chlorella Protothecoides by Heterotrophic Growth in Fermenters. J. Biotechnol., 126, 499-507.

Yao, C-H, Ai, J-N, Cao, X-P, Xue, S. (2013). Salinity manipulation as an effective method for enhanced starch production in the marine microalga Tetraselmis subcordiformis. Bioresource Technology 146, 663-671.

Zarrouk, C. (1966). Contribution à L'étude D'une Cyanophycée: Influence de Divers Facteurs Physiques et Chimiques sur la Croissance et la Photosynthèse de Spirulina maxima (Setch et Gardner) Geitler. Ph.D. Thesis, Faculté des Sciences de l'Université de Paris, Paris, France.

Zhou, N., Zhang, Y., Gong, X., Wang, Q. and Ma, Y. (2012). Ionic liquidsbased hydrolysis of Chlorella biomass for fermentable sugars. Bioresource Technology, 118, 512-517.

Zhu, L.D., Hiltunen, E., Antila, E., Zhong, J.J., Yuang, Z.H. and Wang, Z.M. (2014). Microalgal Biofuel: Flexible Bioenergies for Sustainable Development. Renewable and Sustainable Energy Reviews, 30, 1035. 


\section{الاتجاه التكنولوجي الآمن نحو إنتاج الإيثانول الحيوي من الكتلة الحيوية للطحالب التي تزرع على قش الأرز}

أحمد درويش الجمل'، فوزى جمال خضر ‘، إيمان يوسف تهامي ‘ و أحمد محمد أبوالوفا ‘

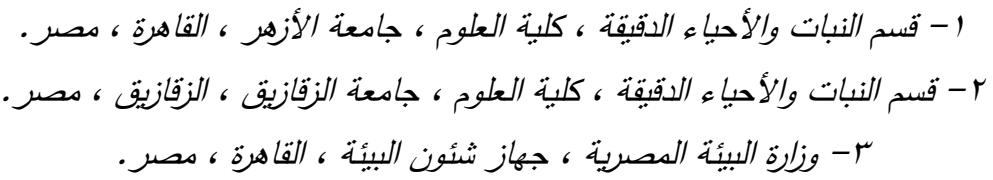

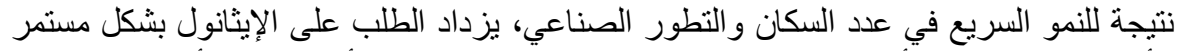

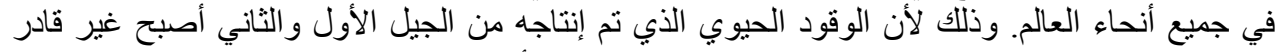

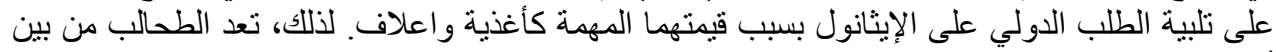

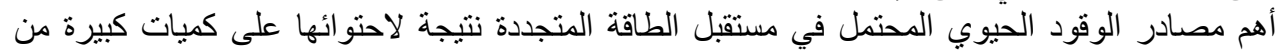

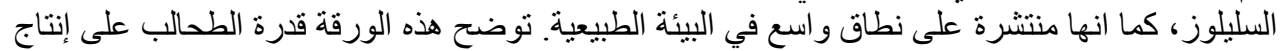

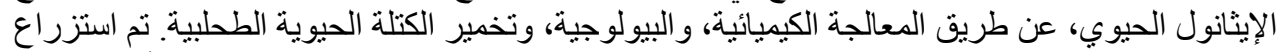

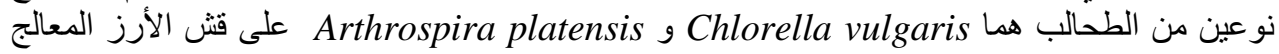

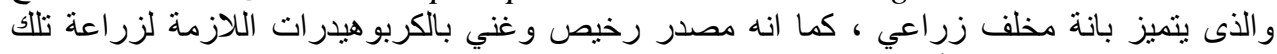

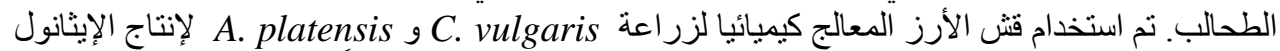

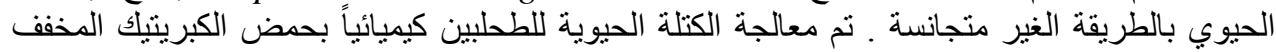

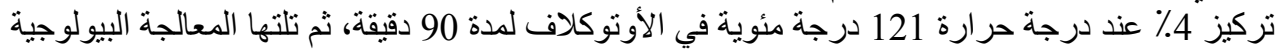

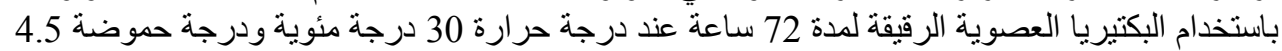

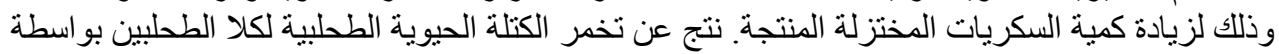
خميرة من نوع Saccharomyces cerevisiae لمدة 72 ساعة ثم التقطير للمحاليل الناتجة من عملية

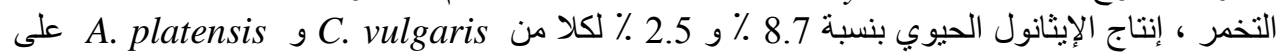

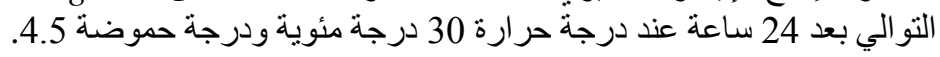

